\title{
The Effect of Hinged Ankle-Foot Orthosis on Walking Function in Children With Spastic Diplegic Cerebral Palsy: A Cross-Sectional Pilot Study
}

\author{
Jeong-Hyeon Kang', Chang-Yong Kim¹, Jin-Moo Ohn², Hyeong-Dong Kim² \\ 'Department of Health Science, The Graduate School, Korea University; ${ }^{2}$ Department of Physical Therapy, College of Health Science, Korea \\ University, Seoul, Korea
}

Purpose: The aim of the current study was to examine the effects of hinged ankle-foot orthosis (HAFO) on walking function in children with spastic diplegic cerebral palsy (CP).

Methods: Thirty-two children (mean age: $6.79 \pm 0.35$ years, age range: 5-7 years) who were diagnosed with spastic diplegic cerebral palsy participated in the study. Each subject typically walked through 10 meters of a gait platform with markers on the subject's proper body segments and underwent 3-D motion analysis system with and without hinged ankle-foot orthosis. The HAFOs were all custom-made for individual $\mathrm{CP}$ children and had plantarflexion stop at $0^{\circ}$ with no dorsiflexion stop. The interventions were conducted over three trials in each group, and measurements were performed on each subject by one examiner in three trials. 3-D motion analysis system was used to measure gait parameters such as walking velocity, cadence, step-length, step-width, stride-length, and double support period in two conditions.

Results: The walking velocity, cadence, step-length, and stride-length were significantly greater for the HAFO condition as compared to the no HAFO condition $(p<0.05)$. However, no significant difference in step-width and double support period was observed between two conditions.

Conclusion: These findings suggest that using the HAFO during walking would suggest positive evidence for improving the spatiotemporal parameters of gait in children with spastic diplegic cerebral palsy.

Keywords: Cerebral palsy, Hinged ankle-foot orthosis, Motion analysis, Walking function

서 론

뇌성마비(cerebral palsy)는 출산 전, 출산 중, 또는 출산 후에 미성숙한 뇌의 다발성 결함과 함께 비진행성 손상으로 인해 야기되는 질병으 로, 영구적이면서도 가변적인 신경발달학적 장애이다. 흔히 뇌성마 비 아동은 감각 소실(sensation loss)이 발생함과 동시에 운동학적 손 상이 동반되며, 주로 하나 또는 그 이상의 팔다리와 몸통에 영향을 미쳐 최종적으로 수의적인 운동 기능을 방해하는 등 다양한 증상을 초래한다. 뇌성마비 아동의 분류는 운동학적 손상이 나타나는 신체 부분에 따라 양하지 마비(diplegia), 편마비(hemiplegia), 그리고 팔다 리 마비(quadriplegia)의 명칭으로 분류가 되며 우세한 비정상적 움직 임에 따라 경직형(spastic), 운동장애형(dyskinetic), 그리고 조화운동 불능형(ataxia)으로 분류한다.2

특히, 뇌성마비 아동의 보행 유형은 위에서 언급한 신체 부위에 따 른 운동 손상과 함께 한쪽 또는 양쪽 부위에서 비정상적인 움직임으 로 인해 정상발달 아동의 보행 유형과 상이한 차이를 나타내고, 더불 어 뇌성마비로 인한 장애의 정도에 따라서도 보행 패턴이 다르게 나 타난다. 뇌성마비 아동의 보행 유형은 내재된 근 경직의 특성과 환경 적 특성 등에 의해 영향을 받으며, 구조적 변화나 제한된 관절가동 성, 그리고 불량 정렬(mal-alignment) 등의 위험을 높일 수 있다.,3 따라 서 뇌성마비 아동의 독립성과 사회적 참여는 아동의 활동성과 연관 되어 있으므로 효율적인 걷기는 뇌성마비 아동의 재활 단계에서 중 요한치료 목표가 된다.5,6

일반적으로 뇌성마비 아동의 효율적인 보행 패턴을 증진시키기 위
Received January 13, 2015 Received February 3, 2015

Accepted February 9, 2015

Corresponding author Hyeong-Dong Kim

E-mail hdkimx1234@daum.net
Copylight ( 2015 The Korean Society of Physical Therapy

This is an Open Access article distribute under the terms of the Creative Commons Attribution Non-commercial License (Http:// creativecommons.org/license/by-nc/3.0.) which permits unrestricted non-commercial use, distribution, and reproduction in any medium, provided the original work is properly cited. 
해 실제 임상에서는 정형외과 및 신경외과적 수술, 신경억제성 약물, 그리고 발목 보조기(ankle foot orthosis) 등을 이용하고 더불어 작업치 료와 물리치료 등을 병행하여 치료한다. 그중, 발목 보조기를 이용한 관리는 뇌성마비 아동의 족부 및 발목의 변형을 방지하고자 임상에 서 부수적인 치료 방법으로 널리 사용되고 있다. 이전의 선행 연구에 서 발목 보조기는 뇌성마비 아동의 발목주위 근육 구축(contracture) 을 방지해주고, 서기 및 보행 기능의 향상과 함께 자세조절을 도우며, 보행 중 역동적인 효율성을 증진시켜 보행의 운동학적(kinematic) 및 동역학적(dynamo-mechanic) 특성과 뇌성마비 아동의 기능적 수행에 대하여 긍정적 효과를 미치는 것으로 보고하였다.3.8-13

특히, 경첩 발목 보조기(hinged ankle-foot orthosis)는 경직성 뇌성마 비 아동의 발이 기능적인 보행을 수행할 수 있도록 고정시키기 위한 목적으로 사용된다. 대부분의 뇌성마비 아동들은 하지의 신전근(extensor)들이 과신장된 형태를 나타내는데, 경첩 발목 보조기를 착용 함으로써 발목을 배측굴곡(dorsiflexion)시키고 아킬레스건(achilles tendon)의 신장(stretching)을 유도하여 하퇴 삼두근(triceps surae muscle)의 경직(spasticity)을 줄여준다. ${ }^{14}$ 경첩 발목 보조기는 족관절이 없 는 경식 발목 보조기(solid ankle foot orthosis)보다 효과적이며 선행 연 구에서는 경첩 발목 보조기를 착용하였을 때 보행 시 입각기(stance) 에서 비교적 자연스런 족관절의 움직임 및 하지 움직임의 대칭(symmetry), 그리고 감소된 무릎의 모멘트(moments)를 보인다고 보고하였 다. ${ }^{14}$ 그 밖의 뇌성마비 아동의 보행 측면에서 운동학(kinematic) 및 운 동역학적(biomechanical) 분석을 통해 경첩 발목 보조기의 긍정적인 효과들이 연구되었다.15-18

하지만 일부 연구에서는 뇌성마비 아동의 경첩 발목 보조기 사용 이 보행 속도(walking velocity)와 보폭(stride length)을 증가시켰으나 분당 보행률(cadence)은 통계학적으로 유의하게 증가하지 못하였 고, ${ }^{19,20}$ 반면에 보폭과 보행 간격(step length) 변수가 증가하여 기능적 능력(functional abilities)을 향상시켰지만 분당 보행률이 오히려 감소 하거나 보행 속도 변화가 없었다고 보고되어 다소 상반된 결과를 나 타내었다. 따라서 본 연구의 목적은 경직성 양하지 뇌성마비 아동에 게 경첩 발목 보조기를 착용하여 보행의 운동학적 특성에 미치는 영 향을 알아보기 위하여 3차원 동작분석기(3-dimentional motion analysis)를 통해 추출된 보행과 연관된 변수들을 비교 및 분석하여 이전 의 선행연구들에서 적은 수의 표본 크기를 대상으로 측정한 점을 보 완하여 객관적인 표본 크기로 관련 연구의 근거를 정량적으로 제시 하고자 한다. 이 연구는 구체적으로 다음의 문제를 해결하고자 경첩 발목 보조기를 착용하지 않았을 때보다 착용하였을 때의 운동학적 보행 변수가 더욱 향상될 것이다라고 연구 가설을 설정하였다.
Table 1. Demographic characteristics of the subjects

$(\mathrm{N}=32)$

\begin{tabular}{lc}
\hline Characteristics & Subjects \\
\hline Gender (Male/Female) $^{*}$ & $17 / 15$ \\
Age (year) & $6.8 \pm 0.4$ \\
Weight (kg) & $23.6 \pm 5.8$ \\
Height (cm) & $118.5 \pm 19.4$ \\
MAS (score) & $1.2 \pm 0.3$ \\
WeeFIM (score) & $63.2 \pm 10.3$ \\
\hline
\end{tabular}

Values are expressed as mean \pm standard deviation.

*Values are numbers.

MAS, Modified ashworth scale; FIM, Functional Independence Measure for children.

\section{연구방법}

\section{1. 연구대상}

본 연구의 대상은 경직성 양하지 뇌성마비로 진단받은 32 명의 아동 (남아 17명, 여아 15명)을 표본으로 선정하였고, 대상자들은 실험에 참가하기 전에 연구 목적과 방법에 대하여 충분히 설명한 뒤 본인 또 는 보호자의 동의를 구하였으며 실험과정은 생명윤리심의위원회의 심의를 거친 후 실시되었다(IRB No.: KU IRB-11-05-P-1). 표본 크기는 이전의 연구되어온 수집된 자료들을 근거로 추정되었고, ${ }^{19,21} \mathrm{General}$ power analysis 프로그램(GPower 3.1)를 이용하여 0.90 통계학적 검증 력(statistical power)을 얻기 위해 최소 30 명의 표본 크기(sample size)가 산출되었다. 위의 표본 크기 계산은 신뢰도 계수를 0.85 로 가정하고, 동일한 집단 내에서 두 가지 조건 사이의 반복 측정된 평균값을 비교 하는 윌콕슨 부호 순위 검정법(Wilcoxon's signed-ranks test)에 기초하 였다. 본 연구에 참여한 모든 대상자들은 경직성 양하지 뇌성마비로 진단받은 아동 중 1) 보조 도구(보행기, 지팡이, 목발 등)를 사용하지 않고, 독립적인 보행이 가능하고, 2) 대동작기능분류시스템(Gross Motor Functional Classification Scale, GMFCS)에서 I 또는 II 수준이 며, ${ }^{13} 3$ ) 근육 경직 척도(modified ashworth scale, MAS)에서 0-1+점을 나타내고, ${ }^{15}$ 4) 아동용 일상생활 기능독립측정(functional independence measure for children, WeeFIM)에서 최소 60점 이상-23에 부합하 는 아동들이 선정되었으며, 12 개월 이내에 정형외과적 또는 신경외과 적 수술을 받은 적이 있거나 근 경련 이완 주사 치료(botulinum, phe$\mathrm{nol}$ 등)를 받은 적이 있는 아동은 본 연구에서 제외하였다. 구체적인 연구대상자의 일반적 특성은 Table 1과 같다.

\section{2. 실험도구 및 측정방법}

1) 경첩 발목 보조기(hinged ankle-foot orthosis)

본 연구에서 사용된 모든 경첩 발목 보조기(E-care Medical Center, Seoul, Korea) (Figure 1)는 서울 소재의 J 재활의학과에서 동일하게 처 

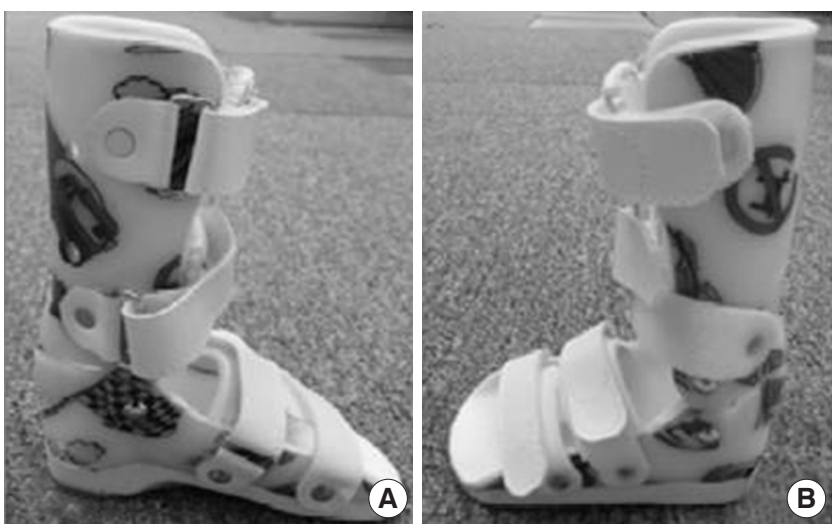

Figure 1. Hinged ankle-foot orthosis used in this study (A) medial, (B) lateral.
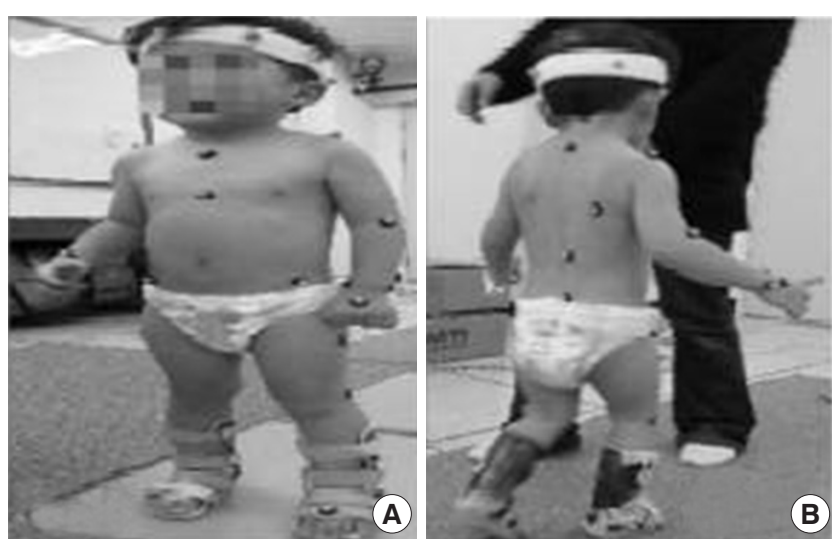

Figure 2. Marker set placements (A) anterior, (B) posterior.

방을 받은 후 각 대상자의 특성에 맞게 제작되었고, $4.8 \mathrm{~mm}$ 두께의 폴 리에스테르(polyester) 재질로 구성되었으며 발가락의 바닥 부위에서 부터 발의 내측 가장자리를 감싸면서 종아리 뒤쪽으로 올라가 무릎 아래의 $2.5-5 \mathrm{~cm}$ 지점까지 연결되도록 제작되었다. ${ }^{24}$ 경첩 발목 보조기 의 관절을 형성하는 경첩은 자유로운 발등 굽힘을 유발할 수 있도록 복사뼈(malleolus) 원위부 끝에 위치하도록 하였고, 배측굴곡이 $0^{\circ}$ 에 이르면 더 이상 저측굴곡(plantarflexion)이 되지 않도록 고안하였다.25

\section{2) 3차원 동작분석기(3-dimentional motion analysis)}

경첩 발목 보조기 착용 유무에 따른 대상자들의 운동학적 보행 변수 에 대한 영상자료를 습득하기 위하여 6대의 적외선 Vicon camera (Vicon, Oxford Metrics Ltd., Oxford, UK)를 대상자의 전방 및 상부에 3개, 후방 및 상부에 3 개를 설치한 후 보행패턴을 촬영하였고, 촬영된 영 상자료는 3차원 동작분석기(Vicon, Oxford Metrics Ltd., Oxford, UK) 를 이용하여 분석하였으며 표본 추출 주파수(sampling frequency)는 $100 \mathrm{~Hz}$ 로 수집하였다. 또한 머리띠를 사용하여 양쪽 이마와 머리 앞 및 뒷부분에 5 개의 마커를 부착하였고, 대상자의 각 관절 주요 표지

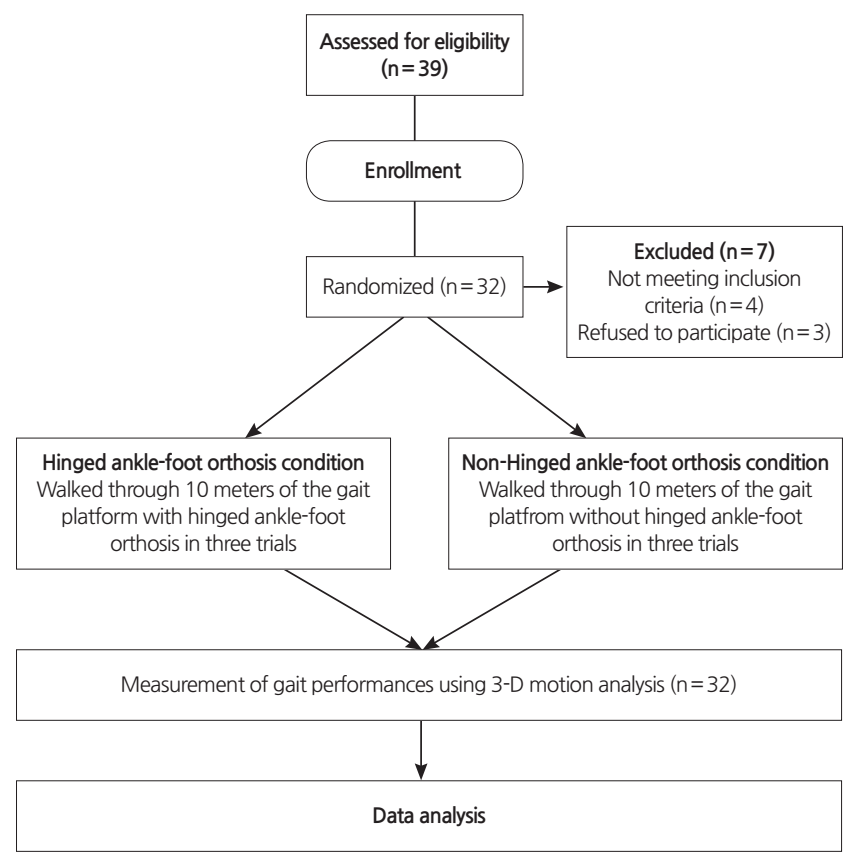

Figure 3. Procedures used in this study.

인 쇄골(clavicle), 흥골(sternum), 견봉(acromion), 주관절의 외측상과 (lateral epicondyle), 수관절의 내측 및 외측 경상돌기(styloid process), 2-3번째 중수골(metacarpal bone) 중간, 전상장골극(anterior superior iliac spine), 천골(sacrum), 대퇴와 경골(tibia) 사이 중간, 슬관절의 외측 상과, 족관절 내측 및 외측상과(malleolus), 아킬레스건, 2-3번째 중족 골(metatarsal bone) 부위에 $14 \mathrm{~mm}$ 구형 반사 마커를 부착하여(Figure 2) 보행 동작에 대한 운동역학적 자료를 수집하였다.

\section{3) 측정방법}

본 연구의 전반적인 실험 절차는 Figure 3 과 같다. 본 연구에 참여한 32 명의 경직성 양하지 뇌성마비 아동에 대해 각각의 조건을 의미하 는 2 개의 카드가 포함되어 있는 상자에서 1 개의 카드를 뽑아서 경첩 발목 보조기 적용 또는 비적용 조건 순서를 무작위 추출법을 사용하 여 정하였다. 연구 결과의 신뢰성을 높이기 위하여 평가 및 자료 분석 을 담당한 연구자는 대상자들의 배정된 조건을 알지 못하도록 하였 다. 모든 대상자들은 몸에 밀착되고 빛에 반사되지 않는 실험복을 편 의에 따라 환복 또는 상의탈의를 하여 실험에 참가하였고, 사전에 목 걸이, 반지 등 금속 물질 및 분석기 신호에 방해가 되는 모든 물건은 몸에서 제거하였으며 신발 착용으로 인한 보행 변수 오차를 최대한 줄이기 위해 맨발인 상태로 측정하였다. 보행을 위한 보행로(walkway)는 $10 \mathrm{~m}$ 로 설정하였고, 보행 속도는 각 대상자의 평소 보행 속도 로 걷도록 하였으며 전체 $10 \mathrm{~m}$ 의 보행 구간 중 보행 시작 시에 나타날 수 있는 비정상적인 패턴과 도착 시에 나타날 수 있는 심리적 반응을 
고려하여 시작과 끝 부분에 각 $1 \mathrm{~m}$ 씩을 제외한 $8 \mathrm{~m}$ 의 범위 내에서 얻 어진 자료를 토대로 결과를 분석하였다. 보행 측정 전에 대상자들은 각각 경첩 발목 보조기를 적용한 상태와 적용하지 않는 상태에서 5 분 동안의 적응시간을 가진 후, 2 번의 예비 실험 이후에 본 실험을 진 행하였고, 각 조건 사이에 3 시간의 간격을 두었다. 보조기 착용 유무 에 따른 보행 분석 비교를 위하여 경첩 발목 보조기 미착용 상태는 착용 상태와 같은 방법으로 다시 한 번 실시하였다. 또한 보행과 관련 된 주의력은 보행 주기(gait cycle)에 따라 달라지기에, ${ }^{26}$ 출발 신호는 구두로 지시하되 출발신호 전 동작은 팔꿈치를 완전히 펴고 시선은 전방을 향하게 한 후 바로 서 있는 자세로 동일하게 취하게 했다. 각 대상자는 경첩 발목 보조기를 착용한 상태와 착용하지 않는 상태에 서 각 조건에 따라 대상자 1 명 당 총 3 번의 보행을 3 번씩 총 9번 실시 하였고, 보행 분석구간은 보행로 전 구간으로 설정하였으며 측정된 보행 변수는 Nexus software (Oxford Metrics Ltd., Oxford, UK)를 사용 하여 3회의 평균값으로 산출하여 평균과 표준편차를 구하였고, 출력 도구로써 Polygon 3.1 (Oxford Metrics Ltd., Oxford, UK)을 사용하여 보 행 속도(walking velocity), 분당 보행률(cadence), 보행 간격(step-length), 보행 넓이(step-width), 보폭(stride-length), 그리고 양하지 지지기(double support period) 변수를 도출하였다.

\section{4) 자료분석 및 통계방법}

본 연구에서의 자료 통계처리는 상용 통계프로그램인 SPSS ver. 12.0 for Windows 통계 프로그램(SPSS Inc., Chicago, IL, USA)을 이용하여 분석하였고, 측정값은 평균과 표준편차로 표시되었다. 본 연구에 수 집된 표본들이 정규성 검정(Kolmogorov-Smirnov test)에서 정규 분포 곡선을 띠고 있지 않으므로, 비모수 검정법(non-parametric method) 을 사용하였다. 동일한 집단 내에서 경첩 발목 보조기 착용 유무 조건 에 따른 운동학적 보행 변수의 차이를 알아보기 위하여 윌콕슨 부호 순위 검정법을 실시하였으며, 가설 수락을 위한 유의수준은 0.05 로 설정하였다.

Table 2. Comparison of kinematic gait parameters between two conditions

$(\mathrm{N}=32)$

\begin{tabular}{lcccc}
\hline Variables & HAFO & Non-HAFO & z & p-value \\
\hline Walking velocity $(\mathrm{m} / \mathrm{sec})^{*}$ & $0.98 \pm 0.10$ & $0.69 \pm 0.04$ & -3.26 & 0.02 \\
Cadence $(\mathrm{step} / \mathrm{min})^{*}$ & $129.93 \pm 20.12$ & $125.78 \pm 26.70$ & -2.79 & 0.03 \\
Step-length $(\mathrm{m})^{*}$ & $0.41 \pm 0.07$ & $0.36 \pm 0.03$ & -2.09 & 0.04 \\
Step-width $(\mathrm{m})$ & $0.13 \pm 0.01$ & $0.14 \pm 0.08$ & 1.32 & 0.19 \\
Stride-length $(\mathrm{m})^{*}$ & $0.91 \pm 0.12$ & $0.60 \pm 0.05$ & -3.25 & 0.03 \\
$\begin{array}{l}\text { Double support period } \\
\text { (\% cycle) }\end{array}$ & $56.91 \pm 8.85$ & $57.72 \pm 7.61$ & 0.23 & 0.81 \\
\hline
\end{tabular}

Values are expressed as mean \pm standard deviation.

${ }^{*} \mathrm{p}<0.05$.

HAFO, Hinged ankle-foot orthosis.

\section{결 과}

위에서 설정된 실험 방법을 토대로 진행한 실험 결과와 그에 따른 자 료 분석 결과는 다음과 같다(Table 2).

\section{1. 보행 속도(Walking velocity)}

보폭을 소요 시간으로 나눈 값인 보행 속도에 대해 분석한 결과, 경첩 발목 보조기를 착용하고 보행을 한 조건의 보행 속도가 $(0.98 \pm 0.10)$ 착용하지 않고 보행을 한 조건의 보행 속도보다 $(0.69 \pm 0.04)$ 통계학적 으로 유의하게 증가하였다 $(\mathrm{z}=-3.26, \mathrm{p}<0.05)$.

\section{2. 보행률(Cadence)}

찍힌 발자국 수를 시간(분)으로 나눈 보행률을 분석한 결과, 경첩 발 목 보조기를 착용하고 보행을 한 조건의 보행률이(129.93 \pm 20.12$)$ 착 용하지 않고 보행을 한 조건의 보행률보다(125.78 \pm 26.70$)$ 통계학적으 로 유의하게 증가하였다 $(\mathrm{z}=-2.79, \mathrm{p}<0.05)$.

\section{3. 보행 간격(Step-length)}

한쪽 발뒤꿈치가 닿을 때부터 다른 쪽 발뒤꿈치가 닿을 때까지의 길 이인 보행 간격을 분석한 결과, 경첩 발목 보조기를 착용하고 보행을 한 조건의 보행 간격이 $(0.41 \pm 0.07)$ 착용하지 않고 보행을 한 조건의 보 행 간격보다 $(0.36 \pm 0.03)$ 통계학적으로 유의하게 증가하였다 $(\mathrm{z}=-2.09$, $\mathrm{p}<0.05)$

\section{4. 보행 넓이(Step-width)}

좌우 양발 사이의 폭을 나타내는 보행 넓이를 분석한 결과, 경첩 발 목 보조기를 착용하고 보행을 한 조건의 보행 넓이가 $(0.13 \pm 0.01)$ 착용 하지 않고 보행을 한 조건의 보행 넓이보다 $(0.14 \pm 0.08)$ 감소하였지만 통계학적으로 유의한차이를 나타내지는 않았다 $(\mathrm{z}=1.32, \mathrm{p}>0.05)$.

\section{5. 보폭(Stride-length)}

보행 시 처음 뒤꿈치가 지면에 닿은 후 동일한 쪽의 뒤꿈치가 다시 지 면에 닿을 때까지의 거리인 보폭을 분석한 결과, 경첩 발목 보조기를 착용하고 보행을 한 조건의 보폭이 $(0.71 \pm 0.12)$ 착용하지 않고 보행을 한 조건의 보폭보다 $(0.60 \pm 0.05)$ 통계학적으로 유의하게 증가하였다 $(\mathrm{z}=-3.25, \mathrm{p}<0.05)$.

\section{6. 양하지 지지기(Double support period)}

보행 주기 동안 좌우 양발이 지면에 접촉되어 있는 비율을 의미하는 양하지 지지기를 분석한 결과, 경첩 발목 보조기를 착용하고 보행을 한 조건의 양하지 지지기가(56.91 \pm 8.85$)$ 착용하지 않고 보행을 한 조 
건의 양하지 지지기보다 $(57.32 \pm 7.61)$ 감소하였지만 통계학적으로 유 의한 차이를 나타내지는 않았다 $(\mathrm{z}=0.23, \mathrm{p}>0.05)$.

\section{고 찰}

경첩 발목 보조기는 경식 발목 보조기와 같이 뇌성마비 아동의 비정 상적인 발목 변형을 지연 및 감소시키고자 실제 임상 분야에서 적용 되고 있으며, 다양한 선행 연구 결과들을 통해 경첩 발목 보조기 착 용이 보행 중 입각기 시에 경골(tibia)의 전방 움직임을 가능하게 하여 비교적 정상적인 배측굴곡을 형성시킴으로써 운동학 및 운동역학적 보행 기능 증진뿐만 아니라 에너지 소비량(energy expenditure) 측면에 서도 효율적이라고 보고하였다. 13,15,25,27,28 하지만 경첩 발목 보조기 착 용 유무에 따라 각각 보행하는 동안의 운동학적 보행 변수에 대하여 다소 상반된 연구결과들이 아직 존재하며19-21 이에 각 변수들이 의미 하는 관련 효과에 대하여 합의점을 도출해내기 힘든 실정이다. 따라 서 본 연구에서는 3 차원 동작 분석기를 이용하여 경직성 양하지 뇌 성마비 아동의 경첩 발목 보조기 착용 유무 조건이 운동학적 보행 변 수에 미치는 영향을 알아보고자 보행과 연관된 변수들을 비교 및 분 석하여 관련 연구의 근거를 정량적으로 제시하고자 하였고, 본 연구 결과 경첩 발목 보조기를 착용하고 보행을 한 조건에서 보행 속도, 보 행률, 보행 간격, 그리고 보폭 변수가 경첩 발목 보조기를 착용하지 않 았을 때 보다 통계학적으로 유의하게 증가하였다.

지금까지 알려진 보행 평가 방법으로는 크게 두 가지가 있는데, 하 나는 보행의 양적인 정보를 얻는 데 유익한 부분거리 측정법이 있다. 이 방법은 임상에서 반복적으로 용이하게 이용할 수 있는 방법 중의 하나로 보행 속도나 보행 거리와 같은 보행 요소를 측정하기 위해 사 용한다. ${ }^{29}$ 하지만 이 방법은 다소 측정자의 주관적인 측정으로 인해 평가 면에서 일반화를 얻기 힘들다는 문제가 있다. ${ }^{30,31}$ 다른 하나는 보 행의 질적인 정보를 얻는데 유익한 컴퓨터를 이용한 삼차원적 동작 분석 방법이 있다. 이 방법은 실험실에서 반복적으로 용이하게 이용 할 수 있는 방법 중의 하나로 삼차원 동작분석기를 통해 추출된 운 동학적 보행 변수를 객관적으로 도출할 수 있다. Patla 등 ${ }^{32}$ 은 이러한 측정법이 정상인의 보행 연구에서 가장 기초가 되는 것으로, 보행 능 력을 평가하는 요소들 중에서 가장 객관적이면서도 중요한 지표라 고 보고하였다. ${ }^{33}$ 이러한 선행 연구자들의 견해에 따라 본 연구에서 는 컴퓨터와 연동한 3 차원 동작분석기를 통해 경첩 발목 보조기 착 용 유무에 따라 경직성 양하지 뇌성마비 아동이 보행 동안의 운동학 적 특정 변수를 측정하였다.

Buckon 등21은 양하지 뇌성마비 아동들을 대상으로 경첩 발목 보 조기, 경식 발목 보조기, 그리고 posterior leaf spring (PLS)를 비교한 연 구에서 경첩 발목 보조기 착용 시에 보폭과 보행 간격이 통계학적으
로 유의하게 증가하였으나, 보행 속도와 보행률은 유의한 변화가 나 타나지 않았다고 보고하였다. 또한, 양하지 뇌성마비 아동들을 대상 으로 경첩 발목 보조기와 경식 발목 보조기의 보행에 대한 효과를 비 교한 다른 선행 연구에서도 보폭의 유의한 변화는 있었으나, 보행 속 도 및 보행률의 유의한 변화는 없다고 보고하였다. ${ }^{13}$ 반면, 편마비 아 동들을 대상으로 한 연구에서는 보폭과 보행 속도가 함께 유의하게 증가하여 본 연구와 비슷한 결과를 보였으나, 보행률의 변화는 관찰 할 수 없었다. ${ }^{11}$ 비록 앞서 언급된 몇몇 연구 결과들에서 보행 속도의 유의한 증가를 발견하지 못하였지만, 수치상으로 증가된 것을 관찰 할 수가 있었다.13,34 Balaban 등든 보행 속도 변수가 증가한 요인에 대 하여 경첩 발목 보조기에 의해 증가된 보폭에 의한 효과라고 서술하 였다. 비록 위에서 언급된 선행연구들의 결과와 본 논문의 결과가 다 소 적은 수의 표본 크기 및 측정장비의 차이로 인해 다소 차이는 발 생한 것으로 사료되지만, 이러한 연구 결과들은 본 연구 결과를 지지 한다고 할 수 있다.

뇌성마비 아동들의 보행 기능에 대해 경첩 발목 보조기가 미치는 효과에 대하여 종합적으로 살펴보면, 경첩 발목 보조기는 유각기 (swing phase) 중에 과도한 저측굴곡을 조절해 주어 초기 닿기(initial contact)에 필요한 발의 선행적 위치조절(pre-position)을 교정함으로 써, ${ }^{34}$ 보통 뇌성마비 아동들의 보행에서 비정상적인 특징으로 나타나 는 첨족보행(toe walking)을 정상에 가깝도록 발뒤꿈치 닿기부터 시작 되는 양상(heel-toe walking)으로 변화시켜 ${ }^{15}$ 발바닥 내에서 정상적인 체중 이동이 가능하도록 돕는다. 그뿐만 아니라, 중간 입각기(midstance phase)와 말기 입각기(terminal-stance phase)에서 경골의 전방 움직임을 유도해주어 더욱 정상적인 배측굴곡을 가능하게 하며, ${ }^{35}$ 결 과적으로 전 유각기(pre-swing phase)의 밀기(push-off) 단계에서 발바 닥 굽힘근들이 추진력을 위한 더 큰 힘을 생성하는 데 도움을 준다. ${ }^{36}$ 이러한 효과들로 인하여 보폭과 보행 간격이 증가되었고, 이는 본 연 구결과의 보행 속도의 증가라는 결과로 이어진 것으로 판단된다. 또 한, Neumann ${ }^{37}$ 은 그의 저서에서 보행 속도의 증가를 위해서는 보폭 또는 보행 간격을 증가시키는 전략과 보행률을 증가시키는 두 가지 전략이 존재하며, 가장 편안한 보폭에 도달한 시점 이후부터 속도의 증가는 보행률의 증가에 의해서만 이루어진다고 보고하였다. 이러한 점으로 미루어 볼 때, 본 연구 결과와 같이 경첩 발목 보조기의 사용 은 위에서 언급된 두 가지 전략을 만족시킴으로써 더욱 증진된 보행 기능을 가능하도록 할 수 있을 것이라 사료된다.

이와 같이 본 연구에서 뇌성마비 아동들의 경첩 발목 보조기의 착 용이 보행 속도를 증가시킨 것을 확인할 수 있었고, 다른 몇몇 선행 연 구들도 이러한 점을 뒷받침해 주었다.13,15,34 이러한 점들을 미루어 보 았을 때, 종합적으로 살펴보면 뇌성마비 아동들의 경첩 발목 보조기 착용은 발목의 비정상적인 움직임을 정상적인 움직임에 가깝게 조절 
하여 보폭 및 보행 간격, 보행률을 증가시키며 보행 주기 전반에 걸쳐 긍정적인 영향을 미쳤다. 이러한 영향은 결과적으로 보행 속도를 증 가시킴으로써 보행 기능을 향상시킨다고 판단된다.

본 연구는 경첩 발목 보조기 착용이 뇌성마비 아동의 보행 기능 향상에 효과적임을 입증하였고, 학문적으로나 실제적으로 경첩 발 목 보조기 관련 연구자나 이용자들에게 유의미한 정보를 제공할 것 으로 보인다. 그럼에도 불구하고, 본 연구는 몇 가지 제한점을 지니고 있으므로 이와 관련된 후속 연구에 대한 방향을 제시하고자 한다. 첫 째, 비교적 짧은 실내에서 측정했기 때문에 보행 속도가 평소 일상 생 활 동작에서의 속도와는 다소 다르게 나왔다는 사실이다. 그러므로 비교적 넓은 실내 공간에서의 움직이는 장애물 등에 대한 보행 패턴 과 더불어 일상 생활 동작과 거의 비슷한 보행 속도를 달리한 추가적 인 연구가 필요하다. 둘째, 본 연구가 많은 수의 뇌성마비 아동들을 대상으로 시행되지 않았기 때문에 본 연구의 결과를 모든 뇌성마비 아동들에게 일반화시켜 적용하는 것에 제한이 따른다. 셋째, 본 연구 는 단편연구(cross-sectional study)로써 경첩 발목 보조기의 즉각적인 효과만을 측정하여 일시적인 변화를 기록하였다. 넷째, 보행의 시.공 간적인 측면만 측정하여 제시함으로써 보행 기능의 단편적인 면에만 초점이 맞추어져 있다. 따라서 향후 연구에서는 위에서 언급한 제한 점을 보완하여 더 많은 수의 대상을 통하여 장기간의 추적 관찰을 시 행함과 더불어 더욱 다양한 환경에서의 보행 기능에 관련된 연구가 지속적으로 이루어져야할 것이다.

\section{ACKNOWLEDGEMENTS}

본 논문의 보조 실험 및 그림 촬영 제공에 도움을 주신 장예은 선생 님께 감사의 말을 전합니다.

\section{REFERENCES}

1. Scherzer AL, Tscharnuter I. Early diagnosis and therapy in cerebral palsy: A primer on infant developmental problems. 2nd ed. New York, Marcel Dkker, 1990.

2. Campbell SK. Physical therapy for children. 3rd ed. Philadelpia, Elsevier, 2005:679-80.

3. Abel MF, Juhl GA, Vaughan CL, et al. Gait assessment of fixed anklefoot orthoses in children with spastic diplegia. Arch Phys Med Rehabil. 1998; 79(2):126-33.

4. Kim SS. Trunk muscle activity of standing and sitting posture in children with cerebral palsy. J Kor Phys Ther. 2004;16(2):367-72.

5. Beckung E, Haqberq G. Neuroimpariments, activity limitions, and participation restrictions in children with cerebral palsy. Dev Med Child Neurol. 2002;44(5):309-16.

6. Noh HR, Kim JS. A Study of needs of families with cerebral palsied children participating in physical therapy intervention. J Kor Phys Ther.
2002;14(2):11-8.

7. Carlson WE, Vauqhan CL, Damiano DL, et al. Orthotic management of gait in spastic diplegia. Am J Phys Med Rehabil. 1997;76(3):219-25.

8. Burtner PA, Woollacott MH, Qualls C. Stance balance control with orthoses in a group of children with spastic cerebral palsy. Dev Med Child Neurol. 1999;41(11):748-57.

9. Degelean M, Borre LD, Salvia P, et al. Effect of ankle-foot orthoses on trunk sway and lower limb intersegemental coordination in children with bilateral cerebral palsy. J Padiatr Rehabil Med. 2012;5(3):171-79.

10. Meadows CB, Condie DN. Report of a Consensus Conference on the Lower Limb Orthotic Management of Cerebral Palsy. Durhan N. Carolina, International Siciety for Prostetic and Orthotics; 1994.

11. Im HY, Jang IS, Bang YS, et al. A study of effect in hemiplegic patients in the hinged plastic ankle foot orthoses and solid plastic ankle foot orthosis. J Kor Phys Ther. 2004;16(3):507-20.

12. Im HY. The immediate effect standing balance and dynamic activity on barefoot, wearing SPAFO and wearing HPAFO in hemiplegic patients. J Kor Phys Ther. 2005;17(1):87-97.

13. Radtka SA, Skinner SR, Johanson ME. A comparison of gait with solid and hinged ankle-foot orthoses in children with spastic diplegic cerebral palsy. Gait Posture. 2005;21(3):303-10.

14. Middleton EA, Hurley GRB, Mcllwain JS. The role of rigid and hinged polypropylene ankle-foot-orthoses in the management of cerebral palsy: A case study. Prosthet Orthot Int. 1988;12(3):129-35.

15. Balaban B, Yasar E, Dal U, et al. The effect of hinged ankle-foot orthosis on gait and energy expenditure in spastic hemiplegic cerebral palsy. Disabil Rehabil. 2007;29(2):139-44.

16. Wilson H, Haideri N, Song K, et al. Ankle-foot orthoses for perambulatory children with spastic diplegia. J Pediatr Orthop. 1997;17(3):370-6.

17. Romkes J, Hell AK, Brunner R. Changes in muscle activity in children with hemiplegic cerebral palsy while walking with and without anklefoot orthoses. Gait Posture. 2006;24(4):467-74.

18. Song CH. Effects of foot orthotic on postural sway. J Kor Phys Ther. 2004;16(2):229-36.

19. Dursun E, Dursun N, Alican D. Effect on gait in children with cerebral palsy. Disabil Rehabil. 2002;24(7):345-7.

20. White H, Jenkins J, Neace WP, et al. Clinically prescribed orthoses demonstrate an increase in velocity of gait in children with cerebral palsy: A retrospective study. Dev Med Child Neurol. 2002;44(4):227-32.

21. Buckon CE, Thomas SS, Jakobson-Huston S. Comparison of three ankle-foot orthosis configurations for children with spastic diplegia. Dev Med Child Neurol. 2004;46(9):590-8.

22. Faul F, Erdfelder E, Lang AG, et al. $G^{\star}$ Power 3: A flexible statistical power analysis program for the social, behavioral, and biomedical sciences. Behav Res Methods. 2007;39(2):175-91.

23. McCabe MA, Granger CV. Content validity of a pediatric functional independence measure. Appl Nurs Res. 1990;3(3):120-2.

24. Butlner P, Nene A. The biomechanics of fixed ankle-foot orthoses and their potential in the management of cerebral palsied children. Physiotherapy. 1991;77(2):81-8.

25. Kuntson L, Clark D. Orthotic devices for ambulation in children with cerebral palsy and myelomeinigocele. Phys Ther. 1991;71(12):947-60.

26. Pagnacco G, Carrick FR, Wright CH, et al. Between-subjects differences of within-subject variability in repeated balance measures: Consequenc- 
es on the minimum detectable change. Gait Posture. 2015;41(1):136-40.

27. Carmick J. Managing equinus in a child with cerebral palsy: Merits of hinged ankle-foot orthoses. Dev Med Child Neurol. 1995;37(11):100610.

28. Dalvand H, Dehghan L, Feizi A, et al. The impacts of hinged and solid ankle-foot orthoses on standing and walking in children with spastic diplegia. Iran J Child Neurol. 2013;7(4):12-9.

29. Hageman PA, Blanke DJ. Comparison of gait of young women and elderly women. Phys Ther. 1986;66(9):1382-7.

30. Ahn CS, Jeong S. A study on gait analysis of normal adult and hemiplegia patients. J Kor Phys Ther. 2002;14(3):143-8.

31. Lee HS, Jeong CJ, Yang HS, et al. Validity and reliability on the walking index for spinal cord injury in walking assessment of the SCI patient. J Kor Phys Ther. 2004;16(3):549-57.

32. Patla AE, Frank JS, Winter DA, et al. Age-related changes in balance control system: Initiation of stepping. Clin Biomech (Bristol, Avon). 1993; 8(4):179-84.

33. Kurz MJ, Stergiou N. Original investigation correlated joint fluctuations can influence the selection of steady state gait patterns in the elderly. Gait Posture. 2006;24(4):435-40.

34. Romkes J, Brunner R. Comparison of a dynamic and a hinged anklefoot orthosis by gait analysis in patients with hemiplegic cerebral palsy. Gait Posture. 2002;15(1):18-24.

35. Ounpuu S, Gage JR, Davis RB. Three dimensional lower extremity joint kinematics in normal pediatric gait. J Pediatr Orthop. 1991;11(3):341-9.

36. Rethlefsen S, Kay R, Dennis S, et al. The effects of fixed and articulated ankle-foot orthoses on gait patterns in subjects with cerebral palsy. J Pediatr Orthop. 1999;19(4):470-4.

37. Neumann DA. Kinesiology of the musculoskeletal system: Foundations for physical rehabilitation. 2nd ed. St Louis, Mosby, 2010:528. 